\title{
Use of Colored Shade Netting in Horticulture
}

\author{
Robert H. Stamps ${ }^{1}$ \\ Department of Environmental Horticulture, University of Florida, Mid-Florida Research and Education Center, \\ 2725 South Binion Road, Apopka, FL 32703-8504
}

Additional index words. cut foliage, disease, flowering, fruiting, photoselective, radiation scattering, shade cloth, vegetative, yield

Higher plants respond to light quantity, quality, direction, and periodicity. There are numerous photoreceptors in plants, including chlorophylls, phtyochromes, cryptochromes, phototropins, and ones that react to green light (Batschauer, 1999; Folta and Maruhnich, 2007). Light, along with other environmental cues, enables plants to adapt to environmental conditions. Efforts to manipulate plant morphology and physiology using photoselective filters have been ongoing for decades, especially in greenhouse environments (Cerny et al., 2003; Ilias and Rajapakse, 2005; Kambalapally and Rajapakse, 1998; Li et al., 2000; Mortensen and Stromme, 1987; Rajapakse and Kelly, 1991, 1992, 1995; Rajapakse et al., 1999; Wilson and Rajapakse, 2001a, 2001b). More recently, colored shade netting (shadecloth) designed specifically for manipulating plant development and growth has become available. These nets can be used outdoors as well as in greenhouses. They can provide physical protection (birds, hail, insects, excessive radiation), affect environmental modification (humidity, shade, temperature) (Pérez et al., 2006), and increase the relative proportion of diffuse (scattered) light as well as absorb various spectral bands, thereby affecting light quality. These effects can influence crops as well as the organisms associated with them.

\section{MICROCLIMATE EFFECTS}

Radiation. Nettings, regardless of color, reduce radiation reaching crops underneath. Obviously, the higher the shade factor, the more radiation will be blocked. Reductions in radiation resulting from netting will affect temperatures (air, plant, soil) and relative humidities (Stamps, 1994). Besides affecting the amount of radiation, nettings can influence the radiation direction.

Radiation scattering. Diffuse light has been shown to increase radiation use efficiency, yields (both at the plant and ecosystem level), and even be a factor affecting plant flowering (timing and amounts) (Gu et al., 2002; Guenter et al., 2008; Healey et al., 1998; Ortiz et al., 2006; Sinclair et al., 1992). Any shade netting can scatter radiation, especially ultraviolet because netting is usually made using ultraviolet-resistant plastic (Wong, 1994). Shade netting that increases light scattering but does not affect

Received for publication 31 Oct. 2008. Accepted for publication 21 Jan. 2009.

${ }^{1}$ To whom reprint requests should be addressed; e-mail rstamps@ufl.edu. the light spectrum has been shown to increase branching, plant compactness, and the number of flowers per plant (Nissim-Levi et al., 2008). Colored shade nets can also increase light scattering by $50 \%$ or more (Fig. 1) and this alone may influence plant development and growth.

Photoselectivity. Colored shade nets are being intensively tested primarily because of their ability to manipulate the spectra of radiation reaching the crops below (Fig. 2). They can be used to change red to far-red light ratios that are detected by phytochromes, the amounts of radiation available to activate the blue/ultraviolet-A photoreceptors, blue light involved in phototropic responses mediated by phototropins, and radiation at other wavelengths that can influence plant growth and development.

Air movement. Nettings also reduce wind speeds and wind run (Stamps, 1994), which can affect temperatures, relative humidities, and gas concentrations resulting from reductions in air mixing (Rosenberg et al., 1983). These changes can affect transpiration, photosynthesis, respiration, and other processes. The effects on air movement depend on the porosity and physical location of the netting in relation to the plants and can be affected by time of day, season, and other factors.

Temperature. Shade nets are often deployed over crops to reduce heat stress (Elad et al., 2007; Retamales et al., 2008; Shahak et al., 2004); however, in enclosed net (shade) houses, temperatures during the day are typically higher than outside (Pérez et al., 2006; Stamps, 1994) and may be lower at night, at least during radiation freezes (Stamps, 1994).

Relative humidity. Relative humidities are often higher under netting than outside as a result of water vapor being transpired by the crop and reduced mixing with drier air outside the netted area (Elad et al., 2007), even when temperatures under the netting are higher than outside (Stamps, 1994).

\section{PLANT EFFECTS}

\section{Vegetative growth}

Blueberries. Black, gray, red, and white nets, with nominal shade percentages of 35 and 50 for each color, were compared with an unshaded control treatment for effects on highbush blueberry cultivar Berkeley growing in central Chile (Retamales et al., 2008). The black net treatments, which reduced photosynthetically active radiation $(P A R)$ the most $(47 \%$ and $54 \%)$, were the main effectors of vegetative growth-increasing internode, leaf and shoot lengths, and leaf widths compared with the no-net control. The other colored nets (gray, red, white) reduced $P A R$ by $29 \%$ to $41 \%$ and had no effect on internode and shoot lengths and minor effects, in a few cases, on the other vegetative parameters (increased leaf length-gray $50 \%$, increased leaf width-all three at 50\% and also gray at $35 \%$ ).

Cast iron plant. Fresh weight of harvested leaves of variegated cast iron plant (Aspidistra elatior 'Variegata') was higher under black netting than under blue, gray, or red and total number of harvestable leaves was higher from under the black than the blue or red netting (Stamps, 2008).

Kiwifruit. An experiment in southern Italy evaluated the effects of blue, gray, red, white, and no nets on Hayward kiwifruit (Basile et al., 2008). The fresh weight of winter prunings was lower in the blue net than in the no-net and red net treatments. Whether this was attributable, in part, to the fact that the blue netting decreased $P A R$ the most, $26.9 \%$ compared with $0 \%$ and $22.8 \%$ for the no-net and red net treatments, respectively, is not known. Vigor control could be beneficial because pruning is a major production cost. The authors also estimated the effects of the nets on summer pruning and concluded that the costs of summer pruning might be greater under the red and gray nets compared with the no-net control.

Orchid. Research from Brazil on a number of Phalaenopsis cultivars and hybrids showed a fairly consistent pattern of enhanced foliage biomass production (fresh and dry weights) under blue netting despite reduced transmission of $P A R$ compared with black and red nets (Leite et al., 2008).

Peach. Based on the weight of pruned material, 30\% blue, gray, pearl, red, yellow, and $12 \%$ white netting all increased vegetative growth of Hermosa peach trees (Shahak et al., 2004).

Philodendron. In a 2-year experiment using black, blue, gray, and red netting with nominal shade factors of $70 \%$, leaf mass of Xanadu philodendron was unaffected but the number of leaves was highest under the red and lowest under the blue netting (Stamps, 2008).

Pittosporum. Oren-Shamir et al. (2001) reported that red netting increased and blue netting decreased branch lengths of variegated pittosporum. They also reported that gray, aluminet, and red netting increased branching compared with black netting; however, the authors did not statistically evaluate the results and examination of the SE bars in their graph suggests that there may have been no increase in branching resulting 


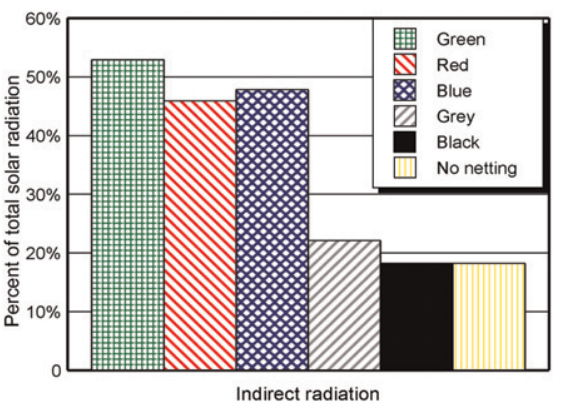

Fig. 1. Light scattering under colored shade nets compared with no net (Oren-Shamir et al., 2001).

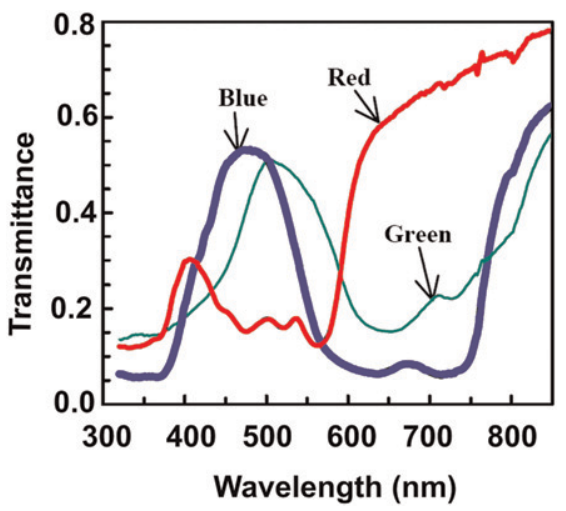

Fig. 2. Spectra of transmittance for three colored shade nets (Oren-Shamir et al., 2001).

from the aluminet and red netting treatments. Production of commercial branches (used by florists) was reduced under blue netting. In the same study, a lower percentage of small leaves (less than $10 \mathrm{~cm}^{2}$ ) and a higher percentage of large leaves (15 to $30 \mathrm{~cm}^{2}$ ) were produced under the green and red netting compared with the conventional black netting. Leaf photosynthesis rates generally paralleled the plant growth parameters. In a 3-year study that also included determinations of Pittosporum tobira 'Variegata' branch yield, production was highest under red, intermediate under gray, and lowest under black and blue netting (Stamps, 2008).

\section{Vegetative quality}

Cast iron plant. Leaf variegation and the percentage of all-green leaves produced was the same under black, blue, gray, and red netting (Stamps, 2008). Netting color had no significant effect on leaf vase life, a critical factor for any cut foliage.

Philodendron. Vase life of Xanadu philodendron leaves was unaffected by netting color (Stamps, 2008).

Pittosporum. In one study (Oren-Shamir et al., 2001), gray netting may have decreased and blue netting may have increased leaf variegation compared with black netting; increased variegation is a desirable outcome for this cut foliage crop. However, no means separation test was conducted by the authors. In another study using similar colors of netting but higher shade factors $(\approx 70 \%)$, treatments did not affect variegation of Pittosporum tobira 'Variegata' (Stamps, 2008). In the first year of the second study, vase life was greatest for stems from the red, intermediate from the gray, and shortest from the black and blue treatments. In the next 2 years, shade net treatments had no effect on vase life.

\section{Flowering}

Kiwifruit. In a study conducted in southern Italy using white, red, blue, and gray netting with shading factors from $20.4 \%$ to $26.9 \%$, numbers of flowers and inflorescences per shoot were lower in the net than nonet treatments (Basile et al., 2008).

Orchid. Red netting, in comparison with black and blue netting (all nominal 30\% shade), induced earlier flowering of nine of 10 Phalaenopsis cultivars and hybrids (Leite et al., 2008).

Peach. After 2 years under netting, flowering of Hermosa peaches was increased by five (white, $12 \%$ shading; blue, pearl, red, and yellow, 30\% shading) of six net treatments compared with the no-net control (Shahak et al., 2004). Only 30\% gray netting did not affect flowering compared with the control.

\section{Fruit quality and yield}

Apple. In a first-year report, Shahak et al. (2004) found that a red/white shade net treatment that reduced $P A R$ by $18 \%$ increased fruit set of apple cultivar Smoothee Golden Delicious (SGD) compared with the no-net control. Although none of the other colored shade net treatments increased SGD fruit set and none, including the red/white treatment, affected 'Topred Red Delicious' (TRD) fruit set, all the net treatments reduced midday stem water potentials (less negative) and prevented sun/heat damage. The stress reduction was likely the result of the shading factors of the nets, which ranged from $\approx 10 \%$ to $36 \%$ for $P A R$ and $19 \%$ to $42 \%$ for ultraviolet-A/ultraviolet-B and resulted in larger SGD fruit size. However, TRD fruit diameters were unaffected by the nets. In contrast, all the shade nets except white improved the midseason red coloration (coverage and intensity) of TRD. Multiple season responses were reported subsequently (Shahak et al., 2008). In each year, the nets were deployed after bloom (early to midMay) and moved aside in early November. SGD fruit size and yield were increased by pearl, red, and white but not by blue, gray, or black nets. For TRD, only the white netting increased fruit size, which the authors attributed to the lower productivity, larger inherent fruit size, and greater plant vigor of TRD compared with SGD.

Blueberries. Interestingly, 35\% gray, 50\% red, and $50 \%$ white nets increased yields of highbush blueberry cultivar Berkeley by $60 \%$ to $91 \%$ in the first year and $26 \%$ to $45 \%$ in the second year, yet $50 \%$ gray and $35 \%$ white did not increase yields, although they transmitted the same amount of PAR despite their nominal shade designations (Retamales et al.,
2008). Spectral analyses under the shade nets were not made. The increased yields were the result of increased fruit set rather than larger fruit and were, according to the authors, great enough to easily justify the cost of installing the nets.

Grapes. A number of studies on table grapes have been reported from Israel (Shahak et al., 2008). Berry and cluster weights of cultivar Superior were increased most under $30 \%$ yellow nets at three locations, but $30 \%$ gray reduced yields compared with the no-net control. Yields were also increased under $30 \%$ black, $30 \%$ red, and $22 \%$ white nets. In other trials using Red Globe as the cultivar, the authors reported increased berry size under the $30 \%$ yellow compared with five other colored nets and increased berry weight under black, red, and white netting compared with no net. Colored netting was also shown to affect the rate of fruit maturation with light-scattering nets (pearl, white) increasing the rate of maturation of a number of cultivars and black and red nets delaying the maturation of 'Red Globe'. With blue netting, maturation was advanced for Superior but delayed for Perlette.

Kiwifruit. Fruit yield (numbers and mass) were reduced by all colored net treatments (blue, gray, red, and white with $P A R$ shading factors of $\approx 20 \%$ to $27 \%$ ); however, increases in fruit size under the nets (except gray) offset the lower yield so that crop values were not different from the no-net control (Basile et al., 2008).

Peach. Fruit set of Hermosa peaches was increased by two net treatments compared with the no-net control (Shahak et al., 2004). The $30 \%$ red net had the greatest effect on the quality of fruit set with three of the other net treatments also benefiting set quality. Fruit size was larger under the nets except under the blue-colored net. However, these larger fruit had lower total soluble solids and firmness.

Pear. Preliminary results indicate that colored shade nets can influence pear fruit size and russeting (Shahak et al., 2008). Pearl netting (30\%) increased large fruit yield and $26 \%$ red netting reduced fruit russeting.

Pepper. Elad et al. (2007) reported increased yields of two Capsicum annuum cultivars when grown under black (nominal $25 \%$ and $40 \%$ shade), blue ( $40 \%$ shade), blue-silver ( $40 \%$ shade), silver $(40 \%)$, and white $(25 \%)$ shade nets as compared with the no-net control. However, there were no differences in total yield when comparing black and white netting (both $25 \%$ nominal shade factor) and the only yield increase comparing $40 \%$ shade factor nets occurred for one cultivar (Louisiana) in which yields under silver netting were higher than under black or blue netting. Data from another experiment reported in that same paper showed that actual shade factors may differ considerably from nominal values and that shade factors change over time. Shahak (2008) reported that production of three cultivars of bell pepper were increased by $16 \%$ to $32 \%$ under pearl and red compared 
with black netting. Unfortunately, the author did not report actual or even nominal shade factors for that study.

\section{Other considerations}

There are many factors to consider regarding the use of colored shade netting besides the direct effects on the crops.

Disease development. Radiation quality can have effects on both plants and the microorganisms associated with them. For example, although pepper yields were increased under colored shade nets as mentioned, powdery mildew (Leveillula taurica) leaf coverage and leaf shedding resulting from disease were more severe in the shade and had to be controlled by spraying (Elad et al., 2007).

Insects and mites. Colored nets may affect mite and insect pests. For example, BenYakir et al. (2008) report that although whiteflies preferred landing on yellow compared with black netting, fewer adult whiteflies were caught on yellow sticky traps inside the yellow-netted chambers than under black-netted ones. However, the number of immature whiteflies counted on cotton leaves inside the chambers were not different.

Effect on humans. Colored nets may directly affect the workers tending the crops (Crane et al., 2008; Elliot and Niesta, 2008; Lin et al., 2008) and also their ability to judge "ripeness" when harvesting a crop.

Netting characteristics. Netting factors like relative costs, color fastness, and durability should also be considered.

\section{SUMMARY}

Colored shade netting is a relatively new tool that can be used for a wide variety of purposes by horticulturists. However, the effects are varied and plant responses may differ even among cultivars of the same plant. Therefore, much additional research is needed to demonstrate and elucidate the effects of colored shade nets. Because colored netting has numerous effects besides photoselective ones, and even photoselectivity can change over time, it is important that researchers provide careful and complete descriptions of experimental conditions. Radiation quality and quantity values and microclimate parameters should be measured and reported to aid in the determination of which factors might be causing any reported results.

\section{Literature Cited}

Basile, B., R. Romano, M. Giaccone, E. Barlotti, V. Colonna, C. Cirillo, Y. Shahak, and M. Forlani. 2008. Use of photo-selective nets for hail protection of kiwifruit vines in southern Italy. Acta Hort. 770:185-192.

Batschauer, A. 1999. Light perception in higher plants. Cell. Mol. Life Sci. 55:153-166.

Ben-Yakir, D., M.D. Hadar, Y. Offir, M. Chen, and M. Tregerman. 2008. Protecting crops from pests using OptiNet ${ }^{\circledR}$ screens and ChromatiNet ${ }^{\circ}$ shading nets. Acta Hort. 770:205-212.

Cerny, T.A., J.E. Faust, D.R. Layne, and N.C. Rajapakse. 2003. Influence of photoselective films and growing season on stem growth and flowering of six plant species. J. Amer. Soc. Hort. Sci. 128:486-491.

Crane, D.K., R.W. Hensarling, A.P. Jung, C.D Sands, and J.K. Petrella. 2008. The effect of light color on muscular strength and power. Percept. Mot. Skills 106:958-962.

Elad, Y., Y. Messika, M. Brand, D.R. David, and A. Sztejnberg. 2007. Effect of colored shade nets on pepper powdery mildew (Leveillula taurica). Phytoparasitica 35:285-299.

Elliot, A.J. and D. Niesta. 2008. Romantic red: Red enhances men's attraction to women. J. Pers. Soc. Psychol. 95:1150-1164.

Folta, K.M. and S.A. Maruhnich. 2007. Green light: A signal to slow down or stop. J. Expt. Bot. 58:3099-3111.

Gu, L.H., D. Baldocchi, S.B. Verma, T.A. Black, T. Vesala, E.M. Falge, and P.R. Dowty. 2002. Advantages of diffuse radiation for terrestrial ecosystem productivity. J. Geophys. Res. 107(D6):ACL 2-1-23.

Guenter, S., B. Stimm, M. Cabrera, M.L. Diaz, M. Lojan, E. Ordonez, M. Richter, and M. Weber. 2008. Tree phenology in montane forests of southern Ecuador can be explained by precipitation, radiation and photoperiodic control. J. Trop. Ecol. 24:247-258.

Healey, K.D., K.G. Rickert, G.L. Hammer, and M.P. Bange. 1998. Radiation use efficiency increases when the diffuse component of incident radiation is enhanced under shade. Aust. J. Agr. Res. 49:665-672.

Ilias, I.F. and N. Rajapakse. 2005. The effects of end-of-the-day red and far-red light on growth and flowering of Petunia $\times$ hybrida 'Countdown Burgundy' grown under photoselective films. HortScience 40:131-133.

Kambalapally, V. and N.C. Rajapakse. 1998. Spectral filters affect growth, flowering, and postharvest quality of Easter lilies. HortScience 33:1028-1029.

Leite, C.A., R.M. Ito, G.T.S. Lee, R. Ganelevin, and M.A. Fagnani. 2008. Light spectrum management using colored nets to control the growth and blooming of Phalaenopsis. Acta Hort. 770:177-184.

Li, S.M., N.C. Rajapakse, R.E. Young, and R. Oi. 2000. Growth responses of chrysanthemum and bell pepper transplants to photoselective plastic films. Scientia Hort. 84:215-225.

Lin, C.J., W.Y. Feng, C.J. Chao, and F.Y. Tseng. 2008. Effects of VDT workstation lighting conditions on operator visual workload. Ind. Health 46:105-111.

Mortensen, L.M. and E. Stromme. 1987. Effects of light quality on some greenhouse crops. Scientia Hort. (Amsterdam) 33:27-36.

Nissim-Levi, A., L. Farkash, D. Hamburger, R. Ovadia, I. Forrer, S. Kagan, and M. OrenShamir. 2008. Light-scattering shade net increases branching and flowering in ornamental pot plants. J. Hort. Sci. Biotechnol. 83:9-14.

Oren-Shamir, M., E.E. Gussakovsky, E. Shpiegel, A. Nissim-Levi, K. Ratner, R. Ovadia, Y.E. Giller, and Y. Shahak. 2001. Coloured shade nets can improve the yield and quality of green decorative branches of Pittosporum variegatum. J. Hort. Sci. Biotechnol. 76:353-361.
Ortiz, E.C., J. Homeier, S.W. Breckle, J. Bendix, P. Emck, M. Richter, and E. Beck. 2006. Seasonality in an evergreen tropical mountain rainforest in southern Ecuador. Ecotropica (Bonn) 12:69-85.

Pérez, M., B.M. Plaza, S. Jiménez, M.T. Lao, J. Barbero, and J.L. Bosch. 2006. The radiation spectrum through ornamental net houses and its impact on the climate generated. Acta Hort. 719:631-636.

Rajapakse, N.C. and J.W. Kelly. 1991. Influence of copper sulfate spectral filters, daminozide and exogenous gibberellic acid on growth of Dendranthema grandiflorum (Ramat.) Kitamura 'Bright Golden Anne'. J. Plant Growth Regul. 10:207-214.

Rajapakse, N.C. and J.W. Kelly. 1992. Regulation of chrysanthemum growth by spectral filters. J. Amer. Soc. Hort. Sci. 117:481-485.

Rajapakse, N.C. and J.W. Kelly. 1995. Spectral filters and growing season influence growth and carbohydrate status of chrysanthemum. J. Amer. Soc. Hort. Sci. 120:78-83.

Rajapakse, N.C., R.E. Young, M.J. McMahon, and R. Oi. 1999. Plant height control by photoselective filters: Current status and future prospects. HortTechnology 9:618-624.

Retamales, J.B., J.M. Montecino, G.A. Lobos, and L.A. Rojas. 2008. Colored shading nets increase yields and profitability of highbush blueberries. Acta Hort. 770:193-197.

Rosenberg, N.J., B.L. Blad, and S.B. Verma. 1983. Microclimate: The biological environment. 2nd Ed. John Wiley \& Sons, New York, NY.

Shahak, Y. 2008. Photo-selective netting for improved performance of horticultural crops. A review of ornamental and vegetable studies carried out in Israel. Acta Hort. 770:161168.

Shahak, Y., E.E. Gussakovsky, Y. Cohen, S. Lurie, R. Stern, S. Kfir, A. Naor, I. Atzmon, I. Doron, and Y. Greenblat-Avron. 2004. ColorNets: A new approach for light manipulation in fruit trees. Acta Hort. 636:609-616.

Shahak, Y., K. Ratner, Y.E. Giller, N. Zur, E. Or, E.E. Gussakovsky, R. Stern, P. Sarig, E. Raban, E. Harcavi, I. Doron, and Y. Greenblat-Avron. 2008. Improving solar energy utilization, productivity and fruit quality in orchards and vineyards by photoselective netting. Acta Hort. 772:65-72.

Sinclair, T.R., T. Shiraiwa, and G.L. Hammer. 1992. Variation in crop radiation-use efficiency with increased diffuse radiation. Crop Sci. 32:1281-1284.

Stamps, R.H. 1994. Evapotranspiration and nitrogen leaching during leatherleaf fern production in shadehouses. SJRWMD Spec. Publ. SJ94SP10. St. Johns River Water Management District, Palatka, FL.

Stamps, R.H. 2008. Differential effects of colored shade nets on three cut foliage crops. Acta Hort. 770:169-176.

Wilson, S.B. and N.C. Rajapakse. 2001a. Growth control of Lisianthus by photoselective plastic films. HortTechnology 11:581-584.

Wilson, S.B. and N.C. Rajapakse. 2001b. Growth regulation of sub-tropical perennials by photoselective plastic films. J. Environ. Hort. 19:6568.

Wong, C.F. 1994. Scattered ultraviolet radiation underneath a shade-cloth. Photodermatol. Photoimmunol. Photomed. 10:221-224. 